\title{
The Purposes of Refugee Education: Policy and Practice of Including Refugees in National Education Systems
}

\section{Citation}

Dryden-Peterson, Sarah, Elizabeth Adelman, Michelle Bellino, and Vidur Chopra. 2019. The Purposes of Refugee Education: Policy and Practice of Including Refugees in National Education Systems. Sociology of Education

\section{Published Version}

10.1177/0038040719863054

\section{Permanent link}

http://nrs.harvard.edu/urn-3:HUL.InstRepos:41343922

\section{Terms of Use}

This article was downloaded from Harvard University's DASH repository, and is made available under the terms and conditions applicable to Open Access Policy Articles, as set forth at http:// nrs.harvard.edu/urn-3:HUL.InstRepos:dash.current.terms-of-use\#OAP

\section{Share Your Story}

The Harvard community has made this article openly available.

Please share how this access benefits you. Submit a story.

\section{Accessibility}




\title{
The Purposes of Refugee Education: Policy and Practice of Including Refugees in National Education Systems
}

\author{
Sarah Dryden-Peterson ${ }^{\mathrm{a}, 1}$, Elizabeth Adelman ${ }^{\mathrm{a}}$, Michelle Bellino ${ }^{\mathrm{b}}$, and Vidur Chopra ${ }^{\mathrm{a}}$

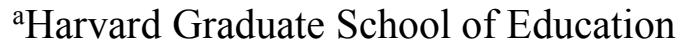 \\ ${ }^{b}$ University of Michigan
}

${ }^{1}$ Dryden-Peterson is the lead author. Adelman, Bellino, and Chopra contributed equally to this article and are listed in alphabetical order.

Corresponding Author:

Sarah Dryden-Peterson

Harvard Graduate School of Education

6 Appian Way

Gutman Library 457

Cambridge, MA 02138 USA

Tel: 617-495-8162/ 617-435-2344

Email: sarah_dryden-peterson@gse.harvard.edu

Elizabeth Adelman

Postdoctoral Fellow

Harvard Graduate School of Education

Michelle Bellino

Assistant Professor

University of Michigan

Vidur Chopra

Postdoctoral Fellow

Harvard Graduate School of Education

\section{Author Biographies}

Sarah Dryden-Peterson is an Associate Professor of Education at the Harvard Graduate School of Education. Her research focuses on education in armed conflict and the ways in which learning, pedagogies, and relationships may alter trajectories of conflict for nation-states and individuals. She has been recognized as a Social Sciences and Humanities Research Council of Canada Postdoctoral Fellow, a National Academy of Education/ Spencer Foundation Postdoctoral Fellow, and a Fulbright Scholar.

Elizabeth Adelman is a postdoctoral fellow at the Harvard Graduate School of Education. Her research explores the experiences of teachers working in conflict-affected settings and how they understand their educational, social, and emotional obligations towards their refugee students. 
She is recipient of the National Academy of Education/ Spencer Foundation Dissertation Fellowship.

Michelle J. Bellino is an Assistant Professor of Educational Studies at the University of Michigan in Ann Arbor. Her research centers on youth citizenship, historical injustice, postconflict reconstruction, and educational reform. She has been recognized as a Peace Scholar by the United States Institute of Peace, a Concha Delgado Gaitan Presidential Fellow by the Council of Anthropology and Education, and a National Academy of Education/ Spencer Foundation Postdoctoral Fellow.

Vidur Chopra is postdoctoral fellow at the Harvard Graduate School of Education. His research examines the ways education policies, programs and practices foster or hinder young people's belonging with their communities and nation-states, during and post-conflict.

\section{Acknowledgements}

We express our thanks to colleagues at the United Nations High Commissioner for Refugees at Headquarters in Geneva, and in field offices in Egypt, Kenya, Rwanda, Bangladesh, Chad, Ethiopia, Iran, Malaysia, Pakistan, South Sudan, Sudan, Syria, Uganda, and Yemen, specifically to Ann Scowcroft, Ita Sheehy, Jacqueline Strecker, and Barbara Zeus; to students at the Harvard Graduate School of Education in the course Education in Armed Conflict in 2013 and 2014 and in the Refugee Education Policy Lab in 2015 (Abigail Russo, Adam Turney, Alexandra Chen, Alexandra Thomas, Allison Celosia, Alyson Gombas, Amal Naeem Qureshi, Amanda Granger, Anita Gurgel, Ann Chang, Anna Kneifel, Anne Awuor, Anne Dwojeski, Antanas Jurksaitis Lukausk, Ashley Lee, Ayako Kubodera, Brian Dooley, Brigid Goggin, Cassandra Walker Harvey, Catherine Gartland, Charlotte Park, Christine Del Vecchio, Daniel Orth, David Grabski, Elizabeth Grossman, Hana Frankova, Heather Pritchard, Heidi Howland, Hyung Joon Kim, Jacqueline Mulders, Jamie Hwang, Janan Omar, Jared Eskenazi, Jeff Thompson, Jim Hahn, Kaitlyn Scott, Kamil Pawlowski, Kasey Boston, Katharine Davis, Katherine Poynton, Keeran Sivarajah, Kelly O'Donnell, Khaled Al-Abbadi, Kim Fernandes, Kristin Barendregt-Ludwig, Laura Barragan Montana, Laura Chrisco, Laura Stankiewicz, Lauren Nelson, Lisa Dipangrazio, Liz Texeira, Lydia Hsu, MacKenzie Monserez, Madeeha Ansari, Marcela Gomez, Maria Romero, Marissa Alberty, Marlana Letelier, Mattew Baunack, Meghan Magee, Meghan Mattern, Michael Childress, Minkyung Cho, Nivedita Chopra, Pratima Patil, Rebecca Vaudreuil, Risako Watanabe, Sam Freedman, Samantha Lakin, Samira Nikaein Towfighian, Sana Mahmood, Sandra Oliveira, Sarah El Nashar, Sarah Hopkinson, Sarah Miano, Sarah Oberst, Seungah Lee, Shazia Khan, Shima Gholamimehrabadi, Suh Yoon Kang, Susan Kippels, Tara McCarney, Taryn Campbell, Tiffany Wong, Tina Robiolle-Moul, Tyler Arnot, Victoria Villalba, Wendy Chen, Yakun Xu, Zainab Hosseini, Zohra Manjee, Bibi-Zuhra Faizi); to Stephanie Bengtsson, Dana Burde, Elisabeth King, Julia Paulson, and Catherine Snow, for feedback on the work. The authors take all responsibility for this work and all errors or omissions are our own.

\section{Research Ethics}

This research was reviewed and approved by the Committee on the Use of Human Subjects at Harvard University (protocol numbers IRB14-0503, IRB14-2199, F23983-101). Permission for data collection was granted by the United Nations High Commissioner for Refugees in Geneva (Headquarters) and in each of the country offices. All interview participants and school staff 
were aware of our roles as academic researchers and provided with an information sheet about the research, its potential risks and benefits, and their rights within the research; all gave their oral consent for participation. All appropriate steps were taken to protect participants' confidentiality.

\section{Funding}

This research was made possible with support from the National Academy of Education/Spencer Foundation, the Weatherhead Center for International Affairs at Harvard University, the Harvard Graduate School of Education, and the United Nations High Commissioner for Refugees under a research-practice Project Partnership Agreement between the Office of the UNHCR and the President and Fellows of Harvard College (project number UNHCR/UNHCR/2014/Pillar1/0000003974/000). This research-practice relationship between UNHCR and the first author allowed access to documents, interviews, meetings, conference calls, and real-time reflection on the processes under study, which would otherwise have remained opaque. While we retained independence in our data collection and analysis, we purposefully incorporated into our research dimensions of implementation processes that were of interest to UNHCR, in line with partnership and our commitments to engaged scholarship that can usefully inform practice and policy. 


\begin{abstract}
This article explores the understood purposes of refugee education at global, national, and school levels. To do so, we focus on a radical shift in global policy to integrate refugees into national education systems and the processes of vernacularization accompanying its widespread implementation. Using a comparative case study approach, our dataset comprises global policy documents and original interviews $(n=147)$ and observations in 14 refugee-hosting nationstates. We analyze how the purposes of refugee education are understood and acted upon by actors occupying diverse positions across these nation-states and over time. We demonstrate that the articulated purposes of refugee education are oriented toward possible futures for refugees, and they presuppose refugees' access to quality education, social belonging, and economic opportunities. Yet across nation-states of exile, we find that refugees' access to these resources is tenuous. Our findings suggest reconceptualizing refugee education to reflect how refugees are simultaneously embedded within multiple national contexts and to address the exclusions they face within each one. This study of refugee education has implications for understanding the purposes of education in other ever-more-common contexts of uncertainty, including the rapid economic and social change brought about by migration, globalization, and technology. Empirically, understanding the purposes of refugee education is critical in a time of unprecedented forced migration.
\end{abstract}

\title{
Keywords
}

Refugee, integration, purposes of education, migration, vernacularization, inclusion 


\section{The Purposes of Refugee Education:}

\section{Policy and Practice of Including Refugees in National Education Systems}

When Aliyah fled Syria with her four children, she imagined returning home within a few months. Like most refugees, she left with only one season of clothes, never expecting her exile would be protracted. Yet when we spoke, she had already been in Egypt for three years. The drawings of her daughter, Manar, always rendered the nostalgia of a once-upon-a-time life in Syria. Manar might envision herself in a different place, her mother explained, if she could go to a "good school." The government schools in the area of Cairo where the family could now afford rent were poor quality, and her mother believed Manar was learning little. The other school options were also problematic: at the costly private school Manar initially attended, her teachers were "warm and caring," but other Egyptian children bullied her incessantly, making her feel unsafe; and the non-formal Syrian school, which was free and followed the Syrian curriculum, kept her connected to a Syrian community but isolated from Egyptian society and the credentials necessary to continue her education in exile.

Manar's life as a refugee in Egypt was filled with the uncertainty of her future, which had implications for determining the criteria for a "good school," a school that would allow her to bridge her present reality with an imagined, yet uncertain, future. Would she return to Syria? If so, the non-formal Syrian school would provide a safe temporary environment and perhaps ease the transition back to school in Syria. Would she remain in exile in Egypt? If so, following the Egyptian curriculum and obtaining Egyptian certification would be critical for her livelihood prospects, and creating strong relationships in Egyptian schools would be worth the challenging, long-term investment. Would she seek to move onward, toward Europe, or would she be formally resettled to a distant country of exile, such as Canada? If so, strong basic skills that 
could transfer to another national context would be key, as would credentials to certify her learning.

In the face of her "unknowable future" (Dryden-Peterson 2017), however, Manar and her family struggled to establish criteria by which they could judge their educational options. Refugee families, along with policymakers and practitioners, struggle daily with this uncertainty of unknowable futures as they make decisions about what curriculum refugees will follow, the languages in which they will learn, the certification they will receive, and the types of schools that might best prepare them for work and life, both in the present and the future. These decisionmaking processes are a productive lens to understand the purposes of refugee education.

The purposes of education are fundamentally political, tackling identification and prioritization of goals that schools should pursue (Labaree 1997:40). As Dewey (1929:97) framed it, reflecting on growing mass education, "[ $\mathrm{t}]$ he conception of education as a social process and function has no definite meaning until we define the kind of society we have in mind." Our analysis of refugee education allows us to consider situations of "radical uncertainty" (Horst and Grabska 2015) in which "the kind of society we have in mind" is both highly unpredictable and contentious. This inquiry necessitates a return to Dewey’s (1929:95) preoccupations, wherein the goals of education are "to educate ... successors not for the existing state of affairs but so as to make possible a future better humanity." Understanding the purposes of refugee education can also inform understanding of the purposes of education in other evermore-common contexts of uncertainty, including rapid economic and social change through migration, globalization, and technology. Empirically, understanding the purposes of refugee education is critical in a time of unprecedented forced migration. 
In this article, we examine the purposes of refugee education through analysis of global refugee education policy and its adaptation in multiple national contexts. We analyze the kinds of knowledge and experiences refugee education prioritizes and the futures for which it seeks to prepare refugee young people. Using a comparative case study approach, our dataset comprises global refugee education policy documents, and interviews and observations related to policy and practice in 14 refugee-hosting nation-states-Bangladesh, Chad, Egypt, Ethiopia, Iran, Kenya, Lebanon, Malaysia, Pakistan, Rwanda, South Sudan, Sudan, Uganda, and Yemen.

We find that the purposes of refugee education, as they are expressed by policies and actors across nation-states, presuppose a "kind of society" (Dewey 1929:97) in which refugees have opportunities to access quality education, develop social belonging, and partake of economic prospects. At the global level, we find that actors working on refugee education focus on inclusion of refugees in national education systems as a pragmatic mechanism for achieving these goals. Yet at the national level, we find multiple models of inclusion: no access to national schools, access to national curriculum and exams but physical isolation from national students, and refugees and nationals studying together in the same spaces. These models reflect nationallevel actors' understandings of refugees' futures and, when enacted at school levels, variably enable or constrain opportunities. We find that access to quality education for refugees, although in theory fostered through policies of inclusion, is absent within national education systems that are themselves of low quality. Prospects of belonging in national schools are even more tenuous, given strained relationships between refugees and nationals, misalignments of possible and preferable futures, and exclusions from post-schooling opportunities. Despite the articulated purpose of refugee education as enabling refugees' futures, access to quality education, belonging, and the economic prospects central to those futures remain elusive. 


\section{REFUGEE EDUCATION}

Refugees have crossed a border due to well-founded fear of persecution. ${ }^{1}$ The number of refugees globally is the highest in recorded history: in $2017,4.4$ million people were newly displaced to become refugees, primarily from Syria, but also with the onset and re-ignition of conflicts in Iraq, Mali, Burundi, and South Sudan, among others. The newly-displaced joined millions who have remained refugees for decades, from ongoing conflicts in Afghanistan, Democratic Republic of Congo (DRC), and Somalia, for example. At the end of 2017, 25.4 million people lived as refugees globally, more than half under the age of 18 (UNHCR 2018a). The vast majority of refugees, 85 percent, live in exile in countries that neighbor their conflictaffected countries of origin (UNHCR 2018a) — this analysis focuses on these populations. These "neighboring host countries" are generally characterized by over-stretched education systems, fragile political and economic institutions, and challenges to inclusion and membership related to their own histories of conflict and division (Hathaway 2016).

Refugees' right to education is articulated in international instruments. The 1951 Convention relating to the Status of Refugees asserts signatory states "shall accord to refugees the same treatment as is accorded to nationals with respect to elementary education ... [and] treatment as favourable as possible ... with respect to education other than elementary education” (UNHCR 2011). In September 2016, the New York Declaration for Refugees and Migrants and the Comprehensive Refugee Response Framework reaffirmed the commitment of United Nations member states "to provide quality primary and secondary education in safe learning environments for all refugee children" (UNGA 2016:14). The United Nations High Commissioner for Refugees (UNHCR) is the global organization mandated with protection of 
refugees, including the provision of services such as education. ${ }^{2}$ As a constituent body, UNHCR coordinates their education work with host countries' governments. Yet despite these provisions, refugees access education at lower rates than do other children. In 2014, during this research, 50 percent of refugees accessed primary school, compared to 93 percent of all children globally; at the secondary level, 25 percent of refugees accessed education, compared to 62 percent globally (Dryden-Peterson 2015). This low access has persisted, with 61 percent attending primary school and 23 percent in secondary school in 2018 (UNHCR 2018b:13).

Since the origins of refugee education during World War II, its purpose has been to prepare refugee students for the future. The nature of this future, however, has not been fixed. Until recently, refugee education policy and practice assumed eventual return to the country of origin. Reflecting that purpose, refugee students were isolated, largely in camps, and attended refugee-only schools in their country-of-origin languages (Dryden-Peterson 2016). The UNHCR Global Education Strategy (GES) 2012-2016 assumed a different future. Given the average length of exile was then estimated as between 10 and 25 years, up to three times as long as in the early 1990s (Devictor and Do 2016; Milner and Loescher 2011), the GES reconceived refugees' likely future to be long-term displacement in host countries (UNHCR 2012). With this anticipated future in mind, the GES adopted an approach of including refugee students in host countries' educational structures, rather than isolating them in parallel systems. The 2018 Global Compact on Refugees and the forthcoming 2019-2030 UNHCR Education Strategy further codified this approach of inclusion (United Nations 2018:13).

\section{PURPOSES OF REFUGEE EDUCATION}

We use findings from comparative case studies to explain how actors at multiple levels understand the purposes of refugee education and what implications these different 
understandings have for access to quality education, social belonging, and economic opportunities. We find, unsurprisingly, a "wild profusion of local practice" (Ball 1994:10), which we seek to understand in the context of a global policy advocating the inclusion of refugees in national education systems. We use the concept of "vernacularization" to analyze variation among the contexts. Vernacularization involves processes of "appropriation and local adoption," particularly the ways ideas "land in very different ways in different places" (Levitt and Merry 2009:445). Following Tsing (2005), we argue that these processes are multidirectional and composed of interactions with origins and destinations across multiple levels. It is in these spaces of interaction, in particular global, national, and school-based actors' decision-making on refugee education, that we locate our inquiry and identify sources of and explanations for variation.

Across contexts, we find a tight connection between conceived possible futures for refugees and understood purposes of refugee education. We also find that the nature of these purposes and futures varies dramatically between contexts. The next sections outline conceptually four possible futures and the ways education might prepare refugees for them. While they do not represent all possible futures, they provide a taxonomy of options around which refugee education policies and practices are enacted.

\section{Possible Futures}

UNHCR (2017:135-9) has long outlined three possible "durable solutions," or futures, for refugees: "resettlement" to a distant country; "return" to the country of origin; or long-term "integration" in the host country. Since 2016, UNHCR has also focused on futures that are geographically fluid and less unidirectional, recognizing ongoing "human mobility" and the "precarious" nature of any possible future (UNGA 2016:1-2). UNHCR does not use the term, 
but we conceptualize this fourth future as "transnationalism." We find that all four futures distinctly shape the understood purposes of refugee education, yet each varies in likelihoodboth real and imagined — for any given refugee and depending on the context. We pay particular attention to the future of integration given its centrality in policy and practice.

\section{The Future of Resettlement}

Resettlement is an unlikely future for refugees, available to less than 1 percent of refugees globally (UNHCR 2014). In resettlement, refugees receive asylum in a distant country, usually one with high Gross National Income (GNI) per capita. Resettlement comes with a high degree of permanency, including a pathway to citizenship unavailable to the vast majority of refugees in neighboring host countries. Refugees, who increasingly find themselves in protracted displacement, often perceive resettlement as the ultimate future, especially in terms of educational possibilities (Dryden-Peterson and Reddick 2017). None of the nation-states in our study are sites of resettlement. However, we consider resettlement in our analysis because refugees in our sites were preoccupied with seeking resettlement, despite its elusiveness, and they thus understood education in light of this future.

\section{The Future of Return}

Facilitation of return to one's country of origin was historically an explicit purpose of refugee education (Dryden-Peterson 2016). Many refugees envision and hope for this future, which educational continuity with the country of origin can facilitate (Fresia and Von Känel 2015). Yet return is an increasingly unlikely future, given the protracted nature of conflict. Education that only prepares refugees for a future of return therefore arguably places them at a 
disadvantage, a rationale that has shaped global policy to include refugees in national education systems. Education oriented toward the country of origin can prevent refugees from accessing opportunities in the host country due to language barriers, limited information networks, and lack of certification or knowledge of how systems in host countries work (see related research on post-education consequences of school-based isolation, e.g., Holdaway, Crul, and Roberts 2009).

\section{The Future of Integration}

Given slim prospects of futures of resettlement or return, long-term exile is an increasingly likely reality for most refugees. As such, we consider three dimensions of education that might enable a future of integration, by which we mean short-term and long-term opportunities in the country of exile. In particular, we examine (1) inclusion in national education systems; (2) access to quality education; and (3) prospects for social belonging.

Access to education is a necessary, if insufficient, step to future labor market participation and poverty reduction (Hanushek 2013). Inclusion in national education systems enables refugees to access schooling at higher rates by addressing common barriers such as lack of infrastructure and limited numbers of teachers (Mendenhall, Russell, and Buckner 2017). Yet even when inclusion is mandated by policy, access can be limited when national systems already struggle to meet nationals' needs or when refugees live in educationally marginalized areas of host countries (Bellino and Dryden-Peterson 2018). At the time of our study, for example, only 41.5 percent of national children were enrolled in primary education in South Sudan (Government of Republic of South Sudan 2013), and in Yemen, only 53.3 percent persisted to grade 6 (Yemen Ministry of Education 2013:22). 
Access to quality education expands economic, social, and civic opportunities (Hanushek and Woessmann 2015), which could enable a future of integration in the country of exile. On the one hand, refugee education might be higher quality within a national system than within separate refugee-only schools given established curriculum, trained teachers, and certification, rationales alluded to within the GES itself (UNHCR 2012:8). Existing curriculum and trained teachers could assist refugees in acquiring skills and knowledge they need to pursue further education or economic livelihoods. Recognized certification could facilitate post-school opportunities within the nation-state of exile, and possibly in the country of origin or transnationally (Kirk 2009). On the other hand, if the quality of education within a national system is low, as in many refugee-hosting countries, then inclusion in the system would not mean access to quality education (Bellino and Dryden-Peterson 2018; Buckner, Spencer, and Cha 2017; Dryden-Peterson 2016). For example, Turkana County in Kenya, where Kakuma refugee camp is located, ranked 45 out of 47 counties in learning outcomes at the end of lower primary (Uwezo 2016). Low-quality education can create gaps between a future of integration in the host country, which inclusion in a national system holds up as possible, and what is actually attainable within that country (Bellino 2018; Chopra 2018), as echoed in the literature on marginalized youth globally (Alba and Foner 2014; Williams 2017).

To facilitate a future of integration, education would need to be high quality and foster a sense of belonging in the society of exile, such as feelings of security, connection, and freedom from discrimination (see, e.g., Hovil 2016; Panter-Brick et al. 2018). Inclusion in national schools could be a space where refugees negotiate their relationships with the nation-state and with host-country nationals, critical elements of preparation for a future of integration. In national schools, refugees are socialized through explicit and implicit messaging of nation-state 
norms that boldly mark boundaries of belonging (Abu El-Haj 2015; Reijerse et al. 2013). This socialization can be productive or destructive, depending on curriculum, pedagogy, and the way relationships are fostered in classrooms (Bajaj and Bartlett 2017; Bar-Tal and Rosen 2009). Following Dewey (1929:95), we might expect education that promotes acceptance of refugees and mitigates their marginalization would usefully prepare young people — both refugee and national—for "a future better humanity" rather than the "existing state of affairs." Yet we also might expect host countries, some with recent histories of identity-based conflicts, to have difficulty adopting this kind of inclusive attitude toward refugees. For example, in Rwanda, norms and rules prevent conversations about ethnicity, limiting possibilities for open discussion about membership and exclusion (King 2014). Furthermore, in most host countries, refugees do not have legal citizenship or access to rights that would enable them to use education to create productive futures, such as the right to work, own property, or access social services (see, e.g., Hovil 2016; Zetter and Ruaudel 2016).

\section{The Future of Transnationalism}

Resettlement, return, and integration represent possible futures that are geographically bounded within nation-states. These nation-state-centric futures do not always reflect the transnational ways refugees seek educational, economic, and social opportunities (DrydenPeterson, Dahya, and Adelman 2017). A fourth possible future is transnational, often encompassing elements of other futures. Unlike futures premised on the cessation of mobility, this future rests on opportunities created by continued mobility, often prompted by refugees' searches for long-term, stable opportunities. Young people in a globalizing world increasingly imagine, plan for, and enact transnational lives, remaining attached to different societies at once 
(Abu El-Haj 2015; Bajaj and Bartlett 2017; Ramirez and Meyer 2012). This is particularly true for refugee youth (Chopra 2018; Dryden-Peterson et al. 2017). Embeddedness in more than one society is a strategy to combat uncertainty and leave open multiple possible futures (Levitt and Jaworsky 2007; Long 2013). ${ }^{3}$

Education could prepare refugees for transnational futures with "transferable skills, knowledge, and capacities" (UNHCR 2012:7) that they could apply no matter where that future might be (Winthrop and McGivney 2016). A transnational future, similar to the future of return, necessitates maintaining language, culture, and identity of the country of origin in addition to acquiring competencies that allow for productive lives in settings of exile (Fresia and Von Känel 2015; Malkki 1995). Challenging this transnational future are restrictions on refugees' rights, which can impede belonging and economic opportunities in exile and in countries of origin (Dryden-Peterson and Reddick 2019). Education that prepares refugees for transnational futures might open up opportunities that exist in what Haddad (2008:7) calls the "gaps between states," but we also consider how pursuing this future can create vulnerabilities, depending on restrictions imposed on refugees by origin and exile nation-states.

\section{METHODOLOGY}

In seeking to understand the purposes of refugee education, we examine the formation of global policy on refugee education and how it was understood and adapted by national-level and school-based actors in 14 nation-states. We chose a comparative case study approach to illuminate how the purposes of refugee education are understood and acted on at multiple levels. We draw on Latour (2005) to conceptualize these levels as non-hierarchical but mutually influential through actors, networks, and relationships. 
Our study is comparative at multiple levels, drawing on case methods (George and Bennett 2005; Gerring 2004; Ragin 2000); focused on mechanism-based explanations (Hedström and Ylikoski 2010), including processes of "vernacularization" (Levitt and Merry 2009); and following the logic of what Bartlett and Vavrus (2017) call "multi-scalar" research, which includes comparisons on three axes. One axis of comparison is horizontal across nation-states, including influences of policies, actors, and ideas between nation-states. The second axis is vertical, comparing policies and practices of refugee education at global, national, and school levels. The third axis is "transversal," over time, situating policies and practices of refugee education in historical contexts as well as examining changes and developments over three years (2012 to 2014) during the introduction of a radically different education strategy. Our approach is sociocultural, focused on understanding how the purposes of refugee education are understood, articulated, and enacted by social actors occupying diverse positions in multiple spaces.

We study the 14 refugee-hosting nation-states where the UNHCR 2012-2016 GES was implemented from 2012 to 2014: Bangladesh, Chad, Egypt, Ethiopia, Iran, Kenya, Lebanon, Malaysia, Pakistan, Rwanda, South Sudan, Sudan, Uganda, and Yemen. ${ }^{4}$ UNHCR chose these nation-states for implementation of the GES due to large refugee populations and educationspecific programming. These nations-states varied on other characteristics, including signatory status to the 1951 Convention, camp or urban location of refugees, and rates of access to education (see Table 1). Their experiences of historical and contemporary conflict also varied, both internal to the nation-state and external with refugees' countries of origin (e.g., Lebanon and Syria). We see these dimensions as constellations of relevant conditions, and we examine how they may influence the perceived purposes of refugee education in each context and subsequent vernacularization. As such, we resist "bound[ing] the case" and instead "follow the 
inquiry" (Bartlett and Vavrus 2017:1) across multiple locations through the phenomenon of interest, namely, implementing a global policy on refugee education. In this way, our study focuses not on the refugee-hosting nation-states themselves, but on the processes of policy and practice vernacularization that occur within these socially-constructed contexts. This trans-spatial approach is particularly suited to a study of refugees, as they are, by definition, ex territoria.

[Table 1 about here]

We designed our data collection methods to make visible connections between ideas, people, and actions (Campbell 2002) across the 14 nation-states, at global, national, and school levels, and over time. To do so, we used multiple methods of data collection, including document analysis, interviews ( $\mathrm{n}=147$ ), and observations (see online Appendix 1 for further explanation of data collection procedures and researchers' positionality).

We analyzed all relevant documents in each of the 14 host countries, including education profiles, operations plans, education mission reports, minutes of meetings with partners, education workshop reports, project reports, and draft national-level education strategies. These documents were made available by UNHCR headquarters in Geneva through a research-practice partnership between UNHCR and Harvard University.

In the first two years of study, we conducted 96 interviews to understand processes of contextualizing the GES in the 14 nation-states. ${ }^{5}$ We interviewed staff members from UNHCR, relevant government offices (e.g., offices of refugee affairs, Ministries of Education), and nongovernment organizations (NGOs) implementing UNHCR's refugee education programs. We conducted these interviews in the context of a for-credit graduate course at the Harvard Graduate School of Education. 
Table 1. Characteristics of Refugee-Hosting Nation-States

\begin{tabular}{|c|c|c|c|c|c|c|c|c|}
\hline \multirow[b]{2}{*}{$\begin{array}{l}\text { Host } \\
\text { Country }\end{array}$} & \multicolumn{4}{|c|}{ Exile Context, as of 2014} & \multicolumn{4}{|c|}{ Education Context, as of 2014 unless otherwise noted } \\
\hline & $\begin{array}{l}\text { Number of } \\
\text { Refugees }\end{array}$ & $\begin{array}{c}\text { Primary Countries } \\
\text { of Origin }\end{array}$ & $\begin{array}{c}\text { Signed } 1951 \\
\text { Convention } \\
\text { (yes/no) }\end{array}$ & $\begin{array}{c}\text { Primary Site(s) of } \\
\text { residence }^{\mathrm{a}} \\
\text { (camp/settlement/urban) }\end{array}$ & $\begin{array}{l}\text { Refugee Primary } \\
\text { Enrollment Rate }\end{array}$ & $\begin{array}{l}\text { National } \\
\text { Primary } \\
\text { NER }\end{array}$ & $\begin{array}{c}\text { Refugee } \\
\text { Secondary } \\
\text { Enrollment Rate }\end{array}$ & $\begin{array}{c}\text { National } \\
\text { Secondary } \\
\text { NER }\end{array}$ \\
\hline Bangladesh & 232,584 & Myanmar & No & Camp & $84 \%$ & $92 \%(2010)$ & $10 \%$ & $48 \%(2012)$ \\
\hline Chad & 454,882 & $\begin{array}{c}\text { Sudan, Central } \\
\text { African Republic } \\
\text { (CAR) }\end{array}$ & Yes & Camp & $55 \%$ & $86 \%(2013)$ & $11 \%$ & $11 \%(2003)$ \\
\hline Egypt & 237,117 & $\begin{array}{c}\text { Iraq, Somalia, Libya, } \\
\text { Syria }\end{array}$ & $Y_{e s}^{b}$ & Urban & $80 \%$ & $95 \%(2011)$ & $81 \%$ & $85 \%(2013)$ \\
\hline Ethiopia & 587,708 & $\begin{array}{l}\text { South Sudan, } \\
\text { Somalia, Eritrea }\end{array}$ & Yes & Camp & $56 \%$ & $65 \%(2006)$ & $23 \%$ & $26 \%(2006)^{\mathrm{e}}$ \\
\hline Iran & 982,071 & Afghanistan, Iraq & Yes & Urban & $80 \%$ & $98 \%(2013)$ & $72 \%$ & $82 \%(2012)$ \\
\hline Kenya & 537,021 & $\begin{array}{l}\text { Somalia, South } \\
\text { Sudan }\end{array}$ & Yes & Camp/ Urban & $65 \%$ & $84 \%(2012)$ & $4 \%$ & $56 \%(2012)$ \\
\hline Lebanon & $1,115,988$ & Syria $^{\mathrm{c}}$ & No & Urban/ Settlement & $37 \%$ & $93 \%(2013)$ & $19 \%$ & $68 \%(2012)$ \\
\hline Malaysia & 98,207 & $\begin{array}{l}\text { Myanmar, Sri Lanka, } \\
\text { Somalia, Iraq, } \\
\text { Afghanistan }\end{array}$ & No & Urban & $47 \%$ & $97 \%(2005)$ & $18 \%$ & $69 \%(2012)^{\mathrm{e}}$ \\
\hline Pakistan & $1,610,355$ & Afghanistan & No & Camp & $43 \%$ & $72 \%(2013)$ & $5 \%$ & $38 \%(2013)$ \\
\hline Rwanda & 72,763 & $\begin{array}{c}\text { Democratic Republic } \\
\text { of Congo (DRC), } \\
\text { Burundi }\end{array}$ & Yes & Camp/ Urban & $75 \%$ & $93 \%(2013)$ & $58 \%$ & $14 \%(2011)^{\mathrm{e}}$ \\
\hline $\begin{array}{l}\text { South } \\
\text { Sudan }\end{array}$ & 240,673 & Sudan, DRC & $\mathrm{No}^{d}$ & Camp & $82 \%$ & $41 \%(2011)$ & $61 \%$ & $2 \%(2011)^{\mathrm{e}}$ \\
\hline Sudan & 240,703 & Eritrea, DRC, Chad & Yes & Camp/ Urban & $58 \%$ & $54 \%(2012)$ & $18 \%$ & n.d. \\
\hline Uganda & 358,453 & $\begin{array}{l}\text { DRC, Somalia, South } \\
\text { Sudan }\end{array}$ & Yes & Settlement/ Urban & $66 \%$ & $91 \%(2013)$ & $20 \%$ & $22 \%(2010)$ \\
\hline Yemen & 245,801 & $\begin{array}{l}\text { Somalia, Iraq, } \\
\text { Ethiopia }\end{array}$ & Yes & Camp/ Urban & $83 \%$ & $88 \%(2013)$ & $80 \%$ & $42 \%(2012)$ \\
\hline
\end{tabular}

a In most host countries in which refugees reside primarily in camps or in rural "settlement" areas (often without the formal designation of a camp yet similar in structure, with limited movement outside the designated territory), there are also refugees living in urban areas. We list any type of residence that comprises over 5 percent of the population.

bEgypt places restrictions on Article 22 of the 1951 Refugee Convention, noting "reservations because these articles consider the refugee as equal to the national" (UNHCR 2011).

"Egypt places restrictions on Article 22 of the 1951 Refugee Convention, noting "reservations because these articles consider the refugee as equal to the national" (UNHCR 2011 ).
d South Sudan, which became an independent nation-state in 2011, ratified the 1969 Organization of African Unity Convention Governing the Specific Aspects of Refugee Problems in Africa, and the government has expressed intent to ratify the 1951 Convention.

${ }^{e}$ Data available only for lower secondary school. 
From our analysis of the documents and interview data, we defined different models of inclusion, and we selected Egypt, Kenya, and Rwanda for in-depth investigation, including at the school level. In these countries, we conducted 34 additional interviews with staff members of UNHCR, government agencies, and NGOs. ${ }^{6}$ We also conducted school-based research, including 17 semi-structured interviews with teachers on their curricular and pedagogical decision-making, their relationships with UNHCR and partner organizations, and how they interpreted the principles of the GES and used them, if at all, in their classrooms. We conducted six classroom observations in these teachers' schools. Additionally, we conducted participant observation of workshops, telephone conferences, working-group meetings, and staff meetings involving UNHCR and partners.

Analysis of data was ongoing and iterative. Immediately following each interview, we wrote narrative profiles for each interview participant (Seidman 2006) to identify emerging themes that informed later interviews. We used the qualitative data analysis software Atlas.ti to code interview notes, fieldnotes from participant observation, and documents, using a process of “consensus coding” (Harry, Sturges, and Klingner 2005). We coded documents and interviews with etic codes derived from policy frameworks (e.g., access for all, quality education, collaboration with government) and emic codes derived through a grounded approach (e.g., refugees as burden, social interactions between refugees and nationals, enforcement of laws). Our goal was to understand the purposes of refugee education as defined by actors in each country and to identify explanatory factors for these purposes. Based on these analyses, we recoded the data focusing on the possible futures these actors envisioned for refugees (resettlement, return, integration, transnationalism). We also focused on integration, coding for mechanisms we identified as enabling a future of integration (inclusion in national education 
systems, access to quality education, prospects of belonging); dimensions of inclusion (curriculum, language, certification, teachers); and models of inclusion (no access to government schools, physically together with nationals, geographically separate from nationals, temporally separate from nationals). We wrote analytic memos to synthesize our analysis across country cases (George and Bennett 2005).

\section{FINDINGS}

Our analyses examine how vernacularization of policies to include refugees in national education systems reflects understood purposes of refugee education and perceived futures for refugees, across 14 countries. We organize our findings by global, national, and school-level approaches, focusing our analysis within each level while also attending to ways they interact and how they operate over time.

\section{Global Level: Access to Quality Education}

In 2012, UNHCR introduced the GES, which focused on "access to quality education for refugees" (UNHCR 2012). To achieve this goal, the GES advocated that refugees be included "within national systems where possible and appropriate and as guided by on-going consultation with refugees" (UNHCR 2012:8). This approach was a departure from past recommendations that education be as closely aligned as possible with the country of origin (INEE 2004; UNHCR 2003, 2009). Our interview participants described five reasons for this policy shift: the protracted nature of conflict, emphasis on access to quality education, presence of refugees in urban areas living among nationals, need for education to facilitate social cohesion, and persistent shortfall and unpredictability in funding. 
Some nation-states had begun to shift toward inclusion prior to the GES. Yet for most countries, uptake of inclusion was a radical shift and happened rapidly after introduction of the GES: in 2010, only five of the 14 nation-states used the national curriculum and language to teach refugee learners; by 2014, this increased to 11 nation-states (see Table 2). By 2014, UNHCR had formal relationships with national authorities in these 11 nation-states to facilitate coordination between UNHCR and governments. When the GES took effect in 2012, UNHCR did not have a single formal relationship on education with a national authority in any country.

The GES was not intended as a global blueprint but instead as strategic objectives to be contextualized within each country. Its design thus anticipated formal processes of vernacularization. An education manager with an NGO in Ethiopia described the global document as the "mother document." A UNHCR staff member based at its headquarters said, "think of the Strategy as a verb, not a noun." Documents created by UNHCR at the global level emphasized analyzing situations in each nation-state to inform decision-making about whether and how to adopt the approach of inclusion. UNHCR (2013) staff in each context engaged in activities designed to answer questions such as: "What does UNHCR hope that children and youth will be educated for in your country context?" Global policy was clear that local capacities, priorities, and conceptions of educational purposes should drive national approaches to refugee education.

Our interviews revealed elements of the GES that global actors believed should be uniform across countries and elements they considered malleable. The principles of access and quality emerged as non-negotiable and essential to the global purposes of refugee education, no matter the nation-state context or imagined future. At the global level, actors equated inclusion in national education systems with access to quality education. Yet, as we explore in the following 
sections, implementation of inclusion policies toward these ends varied dramatically across nation-states, with implications for refugees' future opportunities.

[Table 2 about here]

\section{National Level: Models of Inclusion Reflect Visions of Refugees' Futures}

Each nation-state adopted a contextualized model of inclusion, ranging from no access to government schools (no inclusion), to access to national schools but separation from nationals either geographically or temporally, to full access to government schools with refugees and nationals together in the same classrooms at the same time (see Table 2). Each model reflects prevailing visions of refugees' futures. First, we consider active resistance to inclusion, centered in the idea that refugees' futures will be elsewhere. Next, we consider adoption of inclusion as pragmatic for logistical and financial efficiency, but with no intention of long-term integration. Finally, we consider adoption of inclusion as a means for refugees to create futures of integration in long-term exile. These visions pertain to dynamics driving displacement, particularly the duration of the conflict refugees had fled and historical and contemporary political relationships between refugees and the country of exile. They were also rooted in legal structures beyond educational systems, which could support or impede integration. Data in this section reflect official policy; we turn to the practice of education in the next section.

No inclusion: Refugees' futures will be elsewhere

Malaysia and Bangladesh did not adopt inclusion, and Egypt adopted the model only for Syrian refugees. Contextual factors led to continued preference for separate schools, in particular non-recognition of refugees and an envisioned pathway to resettlement. 
Table 2. Models of Inclusion of Refugees in National Schools

\begin{tabular}{|c|c|c|c|c|c|c|c|c|c|c|c|c|}
\hline \multirow{3}{*}{$\begin{array}{l}\text { Host } \\
\text { Country }\end{array}$} & \multicolumn{4}{|c|}{ Inclusion in National Schools } & \multicolumn{8}{|c|}{ Components of Education } \\
\hline & \multirow[t]{2}{*}{$\begin{array}{c}\text { No } \\
\text { inclusion }\end{array}$} & \multirow[t]{2}{*}{$\begin{array}{l}\text { Physically } \\
\text { together with } \\
\text { nationals }\end{array}$} & \multicolumn{2}{|c|}{ Separated from nationals } & \multicolumn{3}{|c|}{ Curriculum Followed } & \multicolumn{2}{|c|}{$\begin{array}{c}\text { Certification } \\
\text { Provided to refugees }\end{array}$} & \multicolumn{3}{|c|}{$\begin{array}{l}\text { Language of } \\
\text { instruction }\end{array}$} \\
\hline & & & Geographic & Temporal & Host & Origin & Other & Yes & No & Host & Origin & Other \\
\hline \multicolumn{13}{|c|}{ Bangladesh } \\
\hline \multicolumn{13}{|l|}{ Chad } \\
\hline Egypt & $\begin{array}{l}\text { non- } \\
\text { Syrians }\end{array}$ & Syrians & & & Syrians & & $\begin{array}{l}\text { Non- } \\
\text { Syrians }\end{array}$ & Syrians & $\begin{array}{l}\text { Non- } \\
\text { Syrians }\end{array}$ & & & \\
\hline Ethiopia & & Urban & Camp & & & & & & & & & \\
\hline \multicolumn{13}{|l|}{ Iran } \\
\hline Kenya & & Urban & Camp & & & & & & & & & \\
\hline \multicolumn{13}{|l|}{ Lebanon } \\
\hline \multicolumn{13}{|l|}{ Malaysia } \\
\hline \multicolumn{13}{|l|}{ Pakistan } \\
\hline \multicolumn{13}{|l|}{ Rwanda } \\
\hline \multicolumn{13}{|l|}{$\begin{array}{l}\text { South } \\
\text { Sudan }\end{array}$} \\
\hline \multicolumn{13}{|l|}{ Sudan } \\
\hline Uganda & & Urban & Settlement & & & & & & & & & \\
\hline Yemen & & Urban & Camp & & & & & & & & & \\
\hline
\end{tabular}

Source: UNHCR. "Operations plans" from each country $(2012,2013$, and 2014); interviews with UNHCR, government, and NGO staff members in the 14 nation-states ( $\mathrm{n}=134$ ) Note: Shaded cell means that the country adopts the practice listed on the horizontal axis; unshaded cell means that the country does not adopt that practice. 
In Malaysia, participants described the explicit purpose of refugee education as preparing young people for a future of resettlement. This purpose evolved in response to the extremely limited possibility of long-term residence in Malaysia, which is not signatory to the Refugee Convention (see Table 1) and has no legal system for asylum. Without legal status, individuals fleeing to Malaysia are at risk for arrest, detention, and deportation, thus inclusion is at odds with the national policy context. Malaysia therefore has high rates of resettlement. In 2014, 15 percent of all resettled refugees globally departed from Malaysia (UNHCR 2012-2014). Under these conditions, education within national schools — in Bahasa Malay language — was perceived as counterproductive to the envisioned future for refugees. Instead, refugee education took place in separate schools run by NGOs, typically in English, which an NGO staff member explained aimed to foster opportunities upon resettlement, likely in the United States.

In some nation-states, policymakers envisioned different purposes of education for different refugee populations. In Egypt, Syrians were permitted access to national schools, but non-Syrian refugees from Sudan, Somalia, Iraq, Eritrea, and Ethiopia, were not. ${ }^{7}$ Non-Syrians were limited to fees-based private schools or community centers run by NGOs or initiated by refugee communities. Seeing no future of integration in Egypt, centers serving Sudanese refugees elected to follow the Sudanese curriculum so students could obtain Sudanese certificates of education. In 2013, however, the Sudanese government rescinded its policy to grant Sudanese certificates to students who sat for exams in Egypt, which staff at several NGOs attributed to the 2013 coup in Egypt. Although eventually reversed, this situation demonstrated both the political nature of educational decisions and the volatility of education, with implications for refugees' possible futures. 


\section{Inclusion as pragmatic: Refugees are here, for now}

Inclusion frequently developed over time as emergency situations became protracted. In many cases, UNHCR staff members, government officials, and NGOs said they did not shift to such policies because they saw a new purpose for refugee education; inclusion simply became the only feasible option.

Urbanization of refugee populations drove this need, with over 60 percent of refugees living in urban areas by the end of 2015 (UNHCR 2016:53). A Pakistani government official explained that when refugees lived only "inside the camps, it was easy to reach refugees. But now they are all outside the camps," requiring a different model of education. Urban refugee populations drove de facto inclusion in Uganda and Yemen as well, predating the GES.

In addition, during the period of this study, less than 2 percent of all humanitarian funding was allocated to education (Global Education Monitoring Report 2017:7-8). UNHCR staff members across countries highlighted the unpredictability of funding, which made sustained investments in education elusive. An NGO staff member in a camp in Rwanda discussed how the scale at which national education systems operated could absorb some of this volatility: "[I]f we had to initiate our own [refugee] schools, we would have to pay teachers. ... But now because children are integrated in the national schools, the government is taking responsibility. The big responsibility is on the government. The government has to pay teachers; it has to provide the capitation grant for all children—refugees and nationals. It is a good system.” An NGO staff member in Egypt similarly said of inclusion of Syrians into Egyptian schools, "it is easy and it is cheap." Across the 14 countries, however, government officials did not agree, citing costs associated with including refugees in national schools, such as greater wear on school infrastructure due to a larger student population. While they recognized the possibilities for 
efficiencies of scale, in the absence of substantial and predictable external funding, inclusion only shifted the "big responsibility" for refugee education from global to national actors.

Inclusion as creating futures: Refugees are in long-term exile

In some cases, inclusion was explicitly connected to goals of increased access to quality education and creation of a sense of belonging, rooted not only in a pragmatic present but also recognizing a future in long-term exile. The transition from separate schools to inclusion for Sudanese refugees in Chad is illustrative. Until 2014, Sudanese refugees in Chad followed the Sudanese curriculum, attended classes in Arabic, sat for Sudanese exams, and received official school-leaving certificates from the Sudanese government. The shift to the Chadian curriculum was driven by lack of predictable, long-term funding and an increasingly protracted situation, combined with a re-envisioning of the purposes of education for refugees. A UNHCR staff member said "the changing of the curriculum this year ... is how we address education quality. . .. [W]hen we change the curriculum, this will help in gaining support from qualified, certified teachers ... and educational resources from the MoE [Ministry of Education].” Access to quality education for refugees within the national system aligned with goals expressed by UNHCR national staff, NGO staff, and government officials: the possibility of creating a future that could include, but would no longer singularly depend on, a return to Sudan. This framing of refugee education as enabling a possible future of integration, however, was notably absent from formal national policy and public discourse.

\section{School Level: Disconnects between Inclusion and Access to Quality Education and Belonging}


Actors at global levels perceived inclusion in national schools as the foundation for access to quality education, yet practices at national and school levels demonstrated a gulf between those aspirations and refugees' actual experiences of low-quality education.

Contestation over whether and how refugee education was to enable belonging persisted at the school level, tightly aligned to understandings of what types of futures were possible for refugees.

Aspiration: Inclusion enables access to quality education to prepare refugees for multiple futures

The design of refugee education in Rwanda embodied a commitment to the same quality of education for refugees as for nationals. Our interview participants described broad-based support for these goals, from top-level government officials to teachers. "I haven't seen anyone who's against it," said a UN agency staff member. When Rwanda's government expanded feefree education through secondary school, refugees were included in the mandate. A government official described this situation as win-win: "the local population benefitting from the expansion of existing infrastructure and the refugees benefitting from teachers being hired by the government, being paid by the government." For a district government official, the issue was equity: "We allow this [inclusion] because this issue of global education is universal. It's not a country-based policy. It's even in the MDGs [Millennium Development Goals]. So we can't say that Rwandans should complete 12 [years of schooling] but others who are in Rwanda shouldn't study."

An explicit purpose of access to quality education for refugees in Rwanda was to enable multiple futures. A government leader explained that the goal is to "gain ... the skills that could help them in their future anywhere." A refugee teacher in a camp-based school, with students 
primarily from DRC, emphasized ongoing pursuit of a future that could be "anywhere." $\mathrm{He}$ referred to both Rwanda and DRC as "our country," signifying the possible dual nature of his, and his students', futures.

A government leader in Kenya echoed how access to quality education prepared refugees for their "unknowable futures" (Dryden-Peterson 2017): “[F]or refugees they should get the education that would enable them to settle ... to help them fit into society and be a useful member of society ... to help the refugee to integrate." These are the "same skills that any other Kenyan would need," she explained, such as critical thinking, communication skills, and technical skills that match workplace demands they will face in their futures.

One NGO staff member noted the value of a Kenyan education, including outside of Kenya. He explained that even though the Kenyan curriculum, which included English and Kiswahili as languages of instruction, did not explicitly prepare refugees for a future of return, it still could fulfill that role, thus allowing for the simultaneous pursuit of multiple futures. $\mathrm{He}$ articulated the "common knowledge" in South Sudan: "those who can speak English and do something are the people who return from Kakuma [refugee camp in Kenya]."

Given the cyclical nature of conflict and the precarious nature of refugee status in Kenya, another NGO staff member envisioned the need to plan education with these multiple possible futures forefront in mind: "I would like [refugees] to go away with something. ... And for me education would be key. Because even if they relocated to a different country today, they would go with the knowledge, they would go with a paper, something that would help them in their life and the years to come.” To prepare for these multiple futures, a government leader in Kenya underscored the need for children to learn not only to read and write but also to "contribute to nation-building." Preparing refugee students to "contribute to nation-building" was a reoccurring 
theme throughout the data. In practice, what "nation-building" entailed was nebulous, and different actors' visions for where refugees' futures would be had implications for which "nation" education should prepare them to contribute to. One teacher described wanting his students to be in a "position to influence the governance in any country you want to go to.... You need knowledge to change government." He wanted education in exile in Kenya to "make them a better citizen [so] they can transform their society into a better society," wherever that society may be.

Reality: Inclusion in national education systems is inclusion in low-quality education

Our data show that global and national actors equated inclusion with access to quality education for refugees. Yet this aspiration for quality education — and the ways it would prepare refugees for multiple futures — did not reflect actual school-level experiences. For example, in Kenya, the classrooms refugees accessed were so over-crowded-with upward of 200 children at times - that even children sitting next to their teacher could not hear. In Egypt, an NGO staff member noted "there is no benefit" to including Syrian refugees in a system already struggling to implement quality education. In Pakistan, an NGO staff member said, "[i]t is hard to take on [the] additional task of Afghan refugees." As the newest nation-state, challenges of inclusion in South Sudan were similar. South Sudan "is a country in the making," and the Ministry of Education is also "in the making," said a UNHCR staff member. For these reasons, UNHCR staff explained that schools are "barely functional" and act in "haphazard" ways while trying to include refugees.

In Lebanon, less than one third of Lebanese children enroll in government schools, as families with options choose private schools (CERD 2016; Lebanon Ministry of Education and 
Higher Education 2017). A Ministry of Education and Higher Education (MEHE) official expressed concern over exacerbating vulnerabilities of the national education system through inclusion of refugees. "In the beginning of the crisis," she said, "UNHCR was focused on enrolling the refugees in the formal education system, and we were concerned about the stability of our education system and how to keep the level of education as it was before the crisis." Global and national actors decided on a model of inclusion that separated refugees and nationals into two shifts, as a way to negotiate tensions between expanding access to refugees and ensuring the stability of national education. A UNHCR staff member suggested that a second shift was not inclusion, but she described MEHE as immovable on education for refugees that might disadvantage nationals, even if it would enable refugees' futures. An NGO staff member commented on the lose-lose situation created: divided into different shifts, additional funding for refugee education did not strengthen the struggling Lebanese system, and thus neither shift had access to quality education. This had negative implications for the futures of both nationals and refugees. ${ }^{8}$

At times, additional investments by global actors mitigated some of these challenges. In Rwanda, for example, in classes of 60 students, the teachers we observed appeared to know most children's names and, with coaching from a UNICEF-funded program, developed English teaching skills that enabled them to engage students in fluency-developing conversations. National children also benefited from this initiative: with the recent shift in language of instruction from French to English in Rwandan schools, refugees and nationals were Englishlanguage learners together. However, this win-win solution for augmenting access to quality education for refugees and nationals was less possible in nation-states with severely stretched education systems, political instability, or flux in refugee populations. 


\section{Ambivalence: Inclusion to foster belonging?}

Inclusion enabling a sense of belonging for refugees was tenuous across all levels and all nation-states, largely in line with understandings of where refugees' possible futures might be. A government official from Pakistan noted with concern that "[p]reviously we had committed to long-term engagement [with Afghan refugees]," and Pakistan's government had established an education unit for refugees in 1979. Yet, he said, current policies focused on a return to Afghanistan. This vacillation was only the most recent incarnation of volatile notions of belonging for refugees in Pakistan, with implications for their futures and the purposes of education. We see this volatility across our dataset.

Our data overwhelmingly reveal challenges to refugee education as a route to belonging. "If . . we try to put refugees in the school, there is bound to be friction. This creates a horrible situation," explained a government official in Pakistan. A UNICEF staff member working in the same area concluded that refugees do not enroll in school because "they feel they are not welcome there." Similarly, a Lebanese government official described "bullying and discrimination in schools from both sides, against Syrians when the school had more Lebanese students and against Lebanese when the school had a majority of Syrians." Some Sudanese refugees expressed concern to NGO staff over not seeing themselves represented in the Chadian curriculum, noting they "do not want to learn Chadian history." These examples show that simply enrolling refugees in school is not enough to develop an environment of belonging.

In Egypt, all interview participants—no matter their views on inclusion as a policyexplicitly commented on the negative environments in government schools, with little possibility of creating relationships among Egyptians and refugees. Nevertheless, UNHCR staff in Egypt believed including refugees was a top priority because the experience of inclusion might improve 
relations between Syrians and Egyptians, creating opportunities for belonging and conditions for possible futures of integration. Two UNHCR staff members also expressed concerns over the quality of educational alternatives - community centers that were not recognized by the government and often run as businesses.

For Syrian refugees, however, attending formal government schools represented building connections to Egypt and setting down roots, which contradicted their expressed purpose for education: a future of return. Community centers were a preferable "coping mechanism," as one teacher said. The head of one school expressed what he saw as the sentiment of his school body: "They are educating their children temporarily so that they can go back to Syria and rebuild their country."

While on the one hand a response to unwelcoming conditions in government schools, community centers also fostered the kind of belonging Syrian families were seeking. As one NGO staff member said, they were places where teachers were Syrian, students were Syrian, and teachers taught to facilitate a future of return, which reflected the purpose of education espoused by students and families. At the same time, Syrian families and NGOs involved with the community centers expressed concern over their precarity. It is "under the table education," said one NGO staff member. Another NGO staff member, concerned that the Egyptian government would shut down these schools, said it was "a very temporary solution ... it could explode at any point, whenever political change comes."

Aiming to reconcile these tensions, Egypt developed policies to allow accreditation of refugee students' learning in community centers. Refugee children went to the government school once a week for lessons, once a month for tests, and at set intervals for certification exams. Upon graduation with Egyptian certification, Syrian refugees were eligible to enroll in 
Egyptian universities and pay fees as nationals. Yet this arrangement, by which modified inclusion was a pathway toward future opportunities in exile, came with a clear message of exclusion. As one NGO staff member explained, there was an "informal agreement between the headmasters at the public schools" and Syrian families: your children can "register at the school, sit for the exam, but don't bring your children into the classroom." This distancing between national and refugee individuals, and between refugees and state institutions, although problematic, did align with the expressed desires of Syrian families. A UNICEF staff member worried, though, that refugees "are not going to learn to survive living just by themselves." This concern was echoed by an NGO staff member who noted that separation of refugees and nationals in schools created even greater isolation, discrimination, and aggressiveness for everyone.

\section{Inclusion in education to enable integration in society}

Horizontally across nation-states, vertically within each nation-state, and transversally over time, actors expressed a shared view that if refugee education were to enable refugees' futures, conditions of belonging needed to extend beyond school experiences to how refugees were welcomed, or not, into broader social structures. The immediate focus of actors' work was primary education, but the prevalence of this broad, long-term view was striking. Actors situated refugee education in a trajectory that extended beyond primary school to include further levels of education and future economic, social, and political participation. An NGO staff member in Yemen pointed to the objective of education "giving refugees the ability to enter the society and community, and to also explore opportunities to enter the labor market." All our interview participants, to varying degrees, confronted the following question: how possible was this future 
of integration for refugees, if they accessed low-quality education within contexts of few postschooling opportunities even for nationals?

Teachers in Rwanda, Egypt, and Kenya all pointed to misalignment between the expressed purposes of education to enable refugees' futures and actual post-graduation realities. Economic conditions in Egypt were "hellish," teachers from a community school explained, and did not hold opportunities for graduates of any nationality. In Rwanda, the economic success refugees were promised through persistence in school was unreachable. A refugee teacher in Rwanda noted that his own desire for a future of integration in Rwanda was not high, especially when he looked at the lives of Rwandan nationals. "Their lives are not even better," he said bluntly. A teacher in Kakuma refugee camp in Kenya, who arrived from South Sudan as an upper-primary student and completed his secondary schooling in Kenya, also questioned the value of integration into a situation where there are so many "challenges": "[T]here is no future. . .. [I]t gives me a divided mind whether ... I want to be integrated. ... If I am integrated as a citizen of this country, what will be my life? Will it be better or worse than the way I am [now]?" The lack of economic and social opportunities prevented refugees, like these teachers, from building the futures they had hoped their education would make possible.

\section{DISCUSSION AND CONCLUSIONS}

This article documented understandings of the purposes of refugee education at global, national, and school levels, particularly as connected to new policies to include refugees within national education systems. In analyzing these understandings across levels and through the lens of refugees' possible futures, this article makes three central contributions to the sociology of education. First, we document, for the first time, the multiple expressed purposes of refugee 
education held by actors living and working across different levels and within specific nationstates, including the processes by which these ideas developed. Second, we demonstrate the ways that expressed purposes of refugee education intersect with possible futures for refugees. We show that adoption of policies that include refugees in national education systems is premised on belief in creating future opportunities. Yet we also show that poor quality education and lack of prospects for belonging limit opportunities for possible futures, both for refugees and the marginalized nationals amid whom they live and go to school. Third, our findings suggest the need for refugee education theory and practice to deepen engagement with the logics of exclusion and marginalization that influence refugees' education and post-education opportunities, both within nation-states and transnationally.

We found that the purposes of refugee education, at global, national, and school levels, were, as we anticipated, squarely oriented toward preparing refugees for the future. Across all levels, the expressed purposes largely followed a set of perceived possible futures: resettlement, return, integration, and transnationalism. The idea of these futures being "unknowable" was ever-present, yet the ways the stated purposes of education reflected this uncertainty differed across levels and nation-states.

At the global level, the expressed purposes of education reflected pragmatism related to protracted exile and the need for efficient service delivery. The overarching goal was swift access to quality education. Given the length of exile, the global-level approach to this goal hedged toward realistic assumptions that the future most relevant for refugees would be integration into a country of exile. Quality education was presumed to follow from inclusion, including access to national curriculum, language of instruction, teachers, and certification. Global policy also reflected sustainability needs. Given protracted exile and the reliance on 
unpredictable and low levels of international aid, this sustainability could not realistically be accomplished outside of national systems (Betts and Collier 2015; Nicolai and Hine 2015). For actors at the global level, inclusion provided an efficient and longer-term approach to delivering on the goal of quality education for refugees.

At the national level, actors also described the purpose of refugee education as facilitating productive futures for refugees. Given protracted exile, national-level actors generally worked toward including refugees in national education systems. Yet, these actors expressed beliefs that refugees' long-term futures would eventually be outside the nation-states of exile, through resettlement, return, or transnationalism. There was general agreement on what quality education entailed and that it would be useful in any possible future: skills, knowledge, and competencies would allow refugees to find and create jobs and participate in society. Actors at the national level did not perceive their work toward these purposes as nation-state-specific but as transferrable. Education was perceived as a strategy to navigate the unknowable futures refugees faced.

Prospects of belonging were nebulous and dependent on the content of these imagined futures. Some actors believed schools as a mechanism for belonging was in tension with national interests, especially in education systems struggling to provide quality education to nationals and in which national membership and belonging were contested. Moreover, teachers and families often believed that, despite ongoing uncertainty, refugees' futures would, one day, be outside the country of exile. Actors who had contact with refugees on a daily basis - NGO staff members and teachers - underscored refugees' persistent desire to return to their countries of origin or move elsewhere, through resettlement or onward migration. Inclusion might facilitate these futures through access to quality education, but actors across levels were disquieted by the 
exclusion refugees experienced in national schools and how these experiences might preclude learning. These concerns were salient on two dimensions. First was the prevalence of curriculum, pedagogy, and relationships in national schools that prioritized national identities, languages, and histories and therefore marginalized refugees. Second was the lack of post-schooling opportunities for refugees, especially due to legal rights to work and the possibility of being hired given xenophobic practices. These dimensions also affect marginalized nationals, but they are amplified for refugees, who as noncitizens are largely unable to access social protections.

At national and school levels, our data demonstrate how this tension between quality education and belonging is the crux of divergent processes of vernacularization. We uncovered general acceptance, at the policy level, of working toward quality education by including refugees in national education systems, particularly in settings where national education was strong and, in all cases, with regard to certification. However, we heard prevalent and explicit questioning of inclusion at the school level. What was the value of including refugees in schools that were already failing nationals? Despite established national curriculum and trained teachers, including refugees in weak schools, actors argued, would not achieve quality education, for refugees or for nationals. This finding underscores the need for strengthened focus within any inclusion approach on symbiotic relationships between education for refugees and education for nationals. The 2018 Global Compact on Refugees adopts this position and may provide a framework for global responsibility-sharing to increase opportunities for quality education for both refugees and marginalized nationals.

Even in a best-case scenario where refugees are able to access high-quality education within national education systems - including skills, capacities, and knowledge that prepare them for economic and civic participation - refugees often face legal restrictions and opportunity 
structures that limit a future of integration in the country of exile. Does a policy of inclusion, then, thwart the understood purpose of refugee education as enabling futures? Or, might these experiences at global, national, and school levels be the canary in the coalmine to prompt reconceptualization and de-centering of the nation-centric nature of education and post-schooling opportunities, which constrain refugees' future pursuits?

Indeed, we find that the policy of inclusion sets up expectations that refugees could deploy their national education toward a future of integration within the nation-state of exile. Yet actors across nation-states and across levels described the contradictory practices of inclusion, especially the lack of quality education and limited possibilities of belonging. This disconnect is relevant not only for refugees in neighboring host countries, but for growing populations of forcibly displaced individuals in Europe and young people globally who experience "radical uncertainty" (Horst and Grabska 2015) related to what they think their education prepares them for and the opportunity structures they confront after school completion.

Longitudinal research is needed to examine the experiences of refugees throughout their educational trajectories, including secondary school and higher education; their experiences of educational quality and belonging within national schools over time; and the ways they are able to use (or not) their education in the futures they create, be that through resettlement, return, integration, transnationalism, or some combination of these processes. Further research is also needed to understand how refugee education, including through the now-widespread approach of inclusion, might help remake "the kind of society we have in mind" (Dewey 1929:95). In what ways might inclusion transform relationships between refugees and nationals, both inside and outside of schools, with implications for the relationships refugees forge with their nation-states of exile and how they choose to build their futures? 
Given the long-term nature of exile for most refugees, the experiences of inclusion within national education systems that we capture, at the primary level and over three years, are not inconsequential. Our study helps define-for Manar, her mother, and millions of other refugees globally - the criteria for what makes a good school, particularly the dimensions of education that may help individuals with uncertain futures. Our study suggests direct policy implications in three areas.

First, since the 2012 introduction of the global policy of inclusion of refugees in national education systems, refugees have had increased access to education. Yet our research clearly shows that access alone does not forward the universally-expressed purpose of quality education that will help refugees in their various futures. Now that structures of access are in place in many refugee-hosting nation-states, policy and practice must shift to school- and classroom-level experiences — particularly related to curriculum, pedagogy, and relationships — that could augment the quality of education for both refugees and marginalized nationals.

Second, the global-level approach of inclusion pragmatically aims to address the longterm nature of exile. Our data show, however, that this nation-state-centric approach to education does not always reflect how refugees plan for their futures, futures that are often simultaneously embedded in multiple societies in the search for opportunities. The curriculum and pedagogy of refugee education, even within national systems, needs to reflect these multiple possible futures, and schools need to cultivate the skills, knowledge, and competencies that young people can use flexibly across contexts.

Finally, school-level experiences underscore the political nature of where and how refugees are permitted and able to develop a sense of belonging. Even in protracted exile and where refugees are included in national schools, refugees usually do not seek a future of 
integration, which most countries of exile also deem politically untenable. Yet no matter the length of exile, our interview participants emphasized the need for educational spaces that are free from exclusion and discrimination, and for post-schooling opportunities that allow young people to use their education in pursuit of livelihoods and meaningful futures over the duration of exile and beyond. The extreme situation of refugee education highlights ways to re-engage with Dewey's (1929) call to create through schools "the kind of society we have in mind," reflecting collective goals of quality education that enable future opportunities for all. In reflecting these purposes of education, we might "make possible a future better humanity."

\section{NOTES}

${ }^{1}$ In this article, the term "refugee" describes any person with recognized refugee status in a country of asylum. Refugee status may be granted prima facie, meaning it is applied at the group level to all refugees from a particular county (e.g., to all Burundians who flee to Rwanda), or through individual Refugee Status Determination (RSD).

${ }^{2}$ Despite their large numbers, Palestinian refugees are not included in this analysis, as education for Palestinians is notably different than for all other refugees globally and under the mandate not of UNHCR but of the United Nations Relief and Works Agency for Palestinian Refugees (UNRWA).

${ }^{3}$ The concept of "resilience" in the 2016 New York Declaration may reflect this transnational future in a way that was not evident during the research period.

${ }^{4}$ There were some shifts over the three years, due to migration trends and inclusion in GES implementation. Syria was included in the first year, but given conflict dynamics, it was no longer part of implementation in subsequent years; we thus did not include it in our analysis. 
Lebanon and Rwanda were added to the GES in the second year and, despite lacking one year of data, we included them in our analysis, given the richness of data and willingness of participants to help us understand earlier processes.

${ }^{5}$ Bangladesh $(n=7)$, Chad $(n=7)$, Egypt $(n=6)$, Ethiopia $(n=8)$, Iran $(n=7)$, Kenya $(n=8)$, Lebanon $(n=5)$, Malaysia $(n=6)$, Pakistan $(n=8)$, Rwanda $(n=6)$, South Sudan $(n=6)$, Sudan $(\mathrm{n}=6)$, Uganda $(\mathrm{n}=8)$, Yemen $(\mathrm{n}=8)$.

${ }^{6}$ In Egypt, we interviewed 15 staff members of 11 organizations, including UN agencies, international NGOs, and civil society. In Kenya, we interviewed 11 staff members of six organizations, including UN agencies, international NGOs, and the Ministry of Education. In Rwanda, we interviewed eight staff members of six organizations, including UN agencies and three government departments.

${ }^{7}$ In 2017, Egyptian policy shifted to include non-Syrians in national schools.

${ }^{8}$ Lebanon's RACE II Strategy (2017-2021), and its precursor RACE I, aims to improve refugee education vis-à-vis strengthening the national system, with benefits intended to accrue to both refugees and nationals. 


\section{REFERENCES}

Abu El-Haj, Thea Renda. 2015. Unsettled belonging : educating Palestinian American youth after 9/11. Chicago: University of Chicago Press.

Alba, Richard, and Nancy Foner. 2014. "Comparing Immigrant Integration in North America and Western Europe: How Much Do the Grand Narratives Tell Us?" International Migration Review 48(s1):S263-S91.

Bajaj, Monisha, and Lesley Bartlett. 2017. "Critical transnational curriculum for immigrant and refugee students." Curriculum Inquiry 47(1):25-35.

Ball, Stephen J. 1994. Education reform : a critical and post-structural approach. Buckingham.

Bar-Tal, Daniel, and Yigal Rosen. 2009. "Peace Education in Societies Involved in Intractable Conflicts: Direct and Indirect Models." Review of Educational Research 79(2):557-75.

Bartlett, Lesley, and Frances Katherine Vavrus. 2017. Rethinking case study research : a comparative approach. New York: Routledge.

Bellino, Michelle. 2018. "Youth aspirations in Kakuma Refugee Camp: education as a means for social, spatial, and economic (im)mobility." Globalisation, Societies \& Education.

Bellino, Michelle J., and Sarah Dryden-Peterson. 2018. "Inclusion and Exclusion within a Policy of National Integration: Refugee Education in Kenya's Kakuma Refugee Camp." British Journal of Sociology of Education 40(2):222-38.

Betts, Alexander, and Paul Collier. 2015. "Help Refugees Help Themselves: Let Displaced Syrians Join the Labor Market." Foreign Affairs 94(6):84-92.

Buckner, Elizabeth, Dominique Spencer, and Jihae Cha. 2017. "Between Policy and Practice: The Education of Syrian Refugees in Lebanon." Journal of Refugee Studies.

Campbell, J.L. 2002. "Ideas, politics, and public policy." Annual Review of Sociology 28:21-38.

CERD (Committee on the Elimination of Racial Discrimination). 2016. "Statistical Bulletin for the Academic Year." Beirut: CERD.

Chopra, Vidur. 2018. "Learning to Belong, Belonging to Learn: Syrian Refugee Youths' Pursuits of Education, Membership and Stability in Lebanon." Dissertation presented to Harvard University.

Devictor, Xavier, and Quy-Toan Do. 2016. "How Many Years Have Refugees Been in Exile?". Washington, DC: World Bank.

Dewey, John. 1929. Democracy and education; an introduction to the philosophy of education. New York: Macmillan.

Dryden-Peterson, Sarah. 2015. "Refugee education in countries of first asylum: Breaking open the black box of pre-resettlement experiences." Theory and Research in Education:1-18.

Dryden-Peterson, Sarah. 2016. "Refugee Education: The Crossroads of Globalization." Educational Researcher 45(9):473-82.

Dryden-Peterson, Sarah. 2017. "Refugee education: Education for an unknowable future." Curriculum Inquiry 47(1):14-24.

Dryden-Peterson, Sarah, Negin Dahya, and Elizabeth Adelman. 2017. "Pathways to educational success among refugees: Connecting local and global resources." American Educational Research Journal 54(6):1011-47.

Dryden-Peterson, Sarah, and Celia Reddick. 2017. "“When I am a President of Guinea": Resettled Refugees Traversing Education in Search of a Future." European Education 49(4):253-75. 
Dryden-Peterson, Sarah, and Celia Reddick. 2019. "'What I believe can rescue that nation': Diaspora Working Transnationally to Transform Education in Fragility and Conflict." Comparative Education Review, 63(2):213-35.

Fresia, Marion, and Andreas Von Känel. 2015. "Beyond Space of Exception? Reflections on the Camp through the Prism of Refugee Schools." Journal of Refugee Studies.

George, Alexander L., and Andrew Bennett. 2005. Case studies and theory development in the social sciences. Cambridge: MIT Press.

Gerring, J. 2004. "What Is a Case Study and What Is It Good for?" American Political Science Review 98(2):341-54.

Global Education Monitoring Report. 2017. "Aid to education is stagnating and not going to countries most in need." Paris: UNESCO

Government of Republic of South Sudan. 2013. "Education Statistics for the Republic of South Sudan - National Statistics Booklet for 2013." Juba: Government of Republic of South Sudan.

Haddad, Emma. 2008. The refugee in international society : between sovereigns. Cambridge: Cambridge University Press.

Hanushek, Eric A. 2013. "Economic growth in developing countries: The role of human capital." Economics of Education Review 37:204-12.

Hanushek, Eric A., and Ludger Woessmann. 2015. The knowledge capital of nations : education and the economics of growth. Cambridge: The MIT Press.

Harry, Beth, Keith M. Sturges, and Janette K. Klingner. 2005. "Mapping the Process: An Exemplar of Process and Challenge in Grounded Theory Analysis." Educational Researcher 34(2):3-13.

Hathaway, James C. 2016. "A global solution to a global refugee crisis." European papers: a journal on law and integration (1):93-99.

Hedström, Peter, and Petri Ylikoski. 2010. "Causal Mechanisms in the Social Sciences." Annual Review of Sociology 36:49.

Holdaway, Jennifer, Maurice Crul, and Catrin Roberts. 2009. "Cross-National Comparison of Provision and Outcomes for the Education of the Second Generation." Teachers College Record 111(6):1381-403.

Horst, Cindy, and Katarzyna Grabska. 2015. "Introduction: Flight and Exile-Uncertainty in the Context of Conflict-Induced Displacement." Social Analysis 59(1):1-18.

Hovil, Lucy. 2016. Refugees, conflict and the search for belonging. Cham, NY: Springer.

INEE (Inter-agency Network for Education in Emergencies). 2004. Minimum Standards for Education in Emergencies, Chronic Crises and Early Reconstruction. Paris: UNESCO.

King, Elisabeth. 2014. From classrooms to conflict in Rwanda. New York: Cambridge University Press.

Kirk, Jackie (Ed.). 2009. Certification counts: recognizing the learning attainments of displaced and refugee students. Paris: UNESCO-IIEP.

Labaree, David F. 1997. "Public Goods, Private Goods: The American Struggle Over Educational Goals." American Educational Research Journal 34(1):39-81.

Latour, Bruno. 2005. Reassembling the social : an introduction to actor-network-theory. Oxford: Oxford University Press.

Lebanon Ministry of Education and Higher Education. 2017. "RACE Lebanon: Presentation to Education Partners Meeting." Beirut, Lebanon: MEHE. 
Levitt, P. \& Jaworsky, B.N. 2007. "Transnational Migration Studies: Past Developments and Future Trends." Annual Review of Sociology 33:129-56.

Levitt, Peggy, and Sally Merry. 2009. "Vernacularization on the ground: local uses of global women's rights in Peru, China, India and the United States." Global Networks 9(4):44161.

Long, Katy. 2013. The point of no return : refugees, rights, and repatriation. Oxford: Oxford University Press.

Malkki, Liisa H. 1995. Purity and exile : violence, memory, and national cosmology among Hutu refugees in Tanzania. Chicago: University of Chicago Press.

Mendenhall, Mary, Susan Garnett Russell, and Elizabeth Buckner. 2017. "Urban Refugee Education: Strengthening Policies and Practices for Access, Quality, and Inclusion."

Milner, James, and Gil Loescher. 2011. "Responding to protracted refugee situations: Lessons from a decade of discussion." Oxford: Refugee Studies Centre, University of Oxford.

Nicolai, Susan, and Sebastien Hine. 2015. "Investment for education in emergencies: a review of evidence." London: Overseas Development Institute (ODI).

Panter-Brick, Catherine, Kristin Hadfield, Rana Dajani, Mark Eggerman, Alastair Ager, and Michael Ungar. 2018. "Resilience in Context: A Brief and Culturally Grounded Measure for Syrian Refugee and Jordanian Host-Community Adolescents." Child Development.

Ragin, Charles C. 2000. Fuzzy-set social science. Chicago: University of Chicago Press.

Ramirez, Francisco O., and John W. Meyer. 2012. "Toward Post-National Societies and Global Citizenship." Multicultural Education Review 4(1):1-28.

Reijerse, A., K. Van Acker, N. Vanbeselaere, K. Phalet, and B. Duriez. 2013. "Beyond the Ethnic-Civic Dichotomy: Cultural Citizenship as a New Way of Excluding Immigrants." Political Psychology 34(4):611-30.

Seidman, Irving. 2006. Interviewing as qualitative research. New York: Teachers College Press.

Tsing, Anna Lowenhaupt. 2005. Friction : an ethnography of global connection. Princeton: Princeton University Press.

United Nations. 2018. "The global compact on refugees." New York: United Nations.

UNGA (United Nations General Assembly). 2016. "New York Declaration for Refugees and Migrants." New York: United Nations.

UNHCR (United Nations High Commissioner for Refugees). 2003. "Education Field Guidelines." Geneva: UNHCR.

UNHCR (United Nations High Commissioner for Refugees). 2009. "Education Strategy: 20102012." Geneva: UNHCR.

UNHCR (United Nations High Commissioner for Refugees). 2011. "The 1951 Refugee Convention: Reservations and Declarations." Geneva: UNHCR.

UNHCR (United Nations High Commissioner for Refugees). 2012. "Education Strategy 20122016." Geneva: UNHCR.

UNHCR (United Nations High Commissioner for Refugees). 2012-2014. "Resettlement Data Finder." Geneva: UNHCR.

UNHCR (United Nations High Commissioner for Refugees). 2013. "Part II: Guidance for the preparation of national-level refugee education strategies $\&$ the consultative process." Internal document: UNHCR.

UNHCR (United Nations High Commissioner for Refugees). 2014. "Resettlement: A New Beginning in a Third Country." Geneva: UNHCR. 
UNHCR (United Nations High Commissioner for Refugees). 2016. "Global Trends: Forced Displacement in 2015." Geneva: UNHCR.

UNHCR (United Nations High Commissioner for Refugees). 2017. "UNHCR Global Appeal 2017 Update." Geneva: UNHCR.

UNHCR (United Nations High Commissioner for Refugees). 2018a. "Global Trends: Forced Displacement in 2017." Geneva: UNHCR.

UNHCR (United Nations High Commissioner for Refugees). 2018b. "Turn the Tide: Refugee Education in Crisis." Geneva: UNHCR.

Uwezo. 2016. "Are Our Children Learning? Uwezo Kenya Sixth Learning Assessment Report." Nairobi: Twaweza East Africa.

Williams, Timothy P. 2017. "The Political Economy of Primary Education: Lessons from Rwanda." World Development 96:550-61.

Winthrop, Rebecca, and Eileen McGivney. 2016. "Skills for a Changing World: Advancing Quality Learning for Vibrant Societies." Washington, DC: Brookings Institution.

Yemen Ministry of Education. 2013. "Yemen Education Sector Plan Mid Term Results Framework 2013-2015: A document of Ministry of Education." Sana'a, Yemen: Yemen Ministry of Education.

Zetter, Roger, and Héloïse Ruaudel. 2016. "Refugees' Right to Work and Access to Labor Markets - An Assessment." in KNOMAD Working Paper and Study Series. Washington, DC: Global Knowledge Partnership on Migration and Development (KNOMAD). 


\section{Online Appendix 1. Further Notes on Methodology}

\section{Expanded Description of Data Collection}

Document Analysis: We reviewed 56 operations plans, one for each year from 2011 through 2014 for each host country, as well as education fact sheets and other data available for each country context. We also reviewed all guidelines shared by UNHCR Geneva with country offices about national-level education strategy development, as well as minutes from conference calls during which strategy development was discussed. For our three in-depth country casesEgypt, Kenya, and Rwanda — we also analyzed draft and final "education strategies" for each nation-state; in Kenya, Kakuma and Dadaab camps and Nairobi each developed its own strategy, whereas in Egypt and Rwanda there was one strategy for the whole country.

Interviews: Semi-structured interviews in each country context were designed to develop an in-depth understanding of how different actors understood and acted on the goals of the UNHCR Education Strategy and the purposes of refugee education more broadly. We interviewed staff from UNHCR, government agencies, and UNHCR's partner NGOs that implement education programs for refugees and work directly with schools and teachers. Some of these organizations had formal, contractual relationships with UNHCR; others had more informal ad hoc relationships of communication and coordination. We asked them about their organization's role in providing access to education for refugees; the nature of their educational programming; and how they envisioned refugee young people benefiting from their programs now and in the future.

Semi-structured interviews with teachers were designed to understand how they thought about their roles as educators of refugee children, their relationships with UNHCR and partner 
organizations, and how they interpreted the GES principles and used them, if at all, in their classrooms. In Egypt, we conducted interviews and focus groups with seven staff members, both teachers and coordinators, working at three community centers providing education to Syrian refugee students. In Kenya, we conducted interviews with six teachers working in four primary schools. In Rwanda, we interviewed four teachers working in four different primary schools.

Participant Observation: We conducted participant observation in several ways in an effort to understand the way UNHCR and partners communicated and collaborated during daily interactions. We attended and observed one three-day regional workshop in Malaysia, during which staff from select UNHCR country programs, government, and NGO partners participated in developing national-level refugee education strategies, and we conducted six interviews related to the content and process of that workshop. In Kenya and Egypt, we did formal observations of regular meetings, such as Education Working Group meetings, Child Protection Working Group meetings, and UNHCR staff meetings.

We engaged in classroom observations using an open-ended classroom observation guide to deepen our understanding of how refugee children accessed and experienced education in each setting. All efforts were made to observe one class period and interview the teacher following the observation; however, this was not always possible due to time limitations, school schedules, and restrictions on travel in camp settings. In Egypt, school schedules prevented us from conducting any classroom observations. In Kenya, we conducted two classroom observations. In Rwanda, we did four classroom observations. In Kenya and Rwanda, we were able to observe teachers actively teaching (e.g., not testing periods). 


\section{Researcher Positionality}

Unlike most studies in the field of education in conflict, of which refugee education forms a part, this research was not commissioned. It was undertaken as part of a researchpractice partnership between UNHCR and Harvard University. This relationship allowed access to documents, interviews, meetings, conference calls, and real-time reflection on the processes under study, which would otherwise have remained opaque. We retained independence in our data collection and analysis, but we purposefully incorporated dimensions of the implementation process that were of interest to UNHCR, in line with our partnership and our commitment to engaged scholarship that can usefully inform practice and policy. We were consistently aware in the course of the research of our position as outsiders, not only in refugee settings but also within the global bureaucracy of UNHCR and its partner organizations. We explicitly attempted to create lines of connection with our research participants as well as to intensely probe assumptions and misconceptions as they arose. Our analytic processes incorporated ongoing reflection, as a team, on the ways our identities and experiences were shaping our views of the data and analysis. 